\title{
Evaluation of the influence of dental bleaching with $35 \%$ hydrogen peroxide in orthodontic bracket shear bond strength
}

\author{
Marcus Vinicius Neiva Nunes do Rego, Roanselli Marllon Lima dos Santos², \\ Leanne Matias Portela Leal ${ }^{3}$, Carlos Gustavo Silva Braga ${ }^{4}$
}

Objective: The purpose of this study was to evaluate, in vitro, the bond strength of brackets bonded to premolars previously subjected to bleaching with a 35\% hydrogen peroxide. Methods: Twenty one healthy premolars were selected and randomly divided into three groups $(\mathrm{n}=7)$. Group I (G1) included teeth that were not submitted to bleaching. The enamel surfaces of Groups II (G2) and III (G3) were submitted to a bleaching process with 35\% hydrogen peroxide (Whiteness HP Maxx). On Group II (G2), after bleaching, the teeth were stored for 24 hours in distilled water at 98.6 ${ }^{\circ} \mathrm{F}$, and then, premolar metallic brackets were bonded using Transbond XT (3M) resin. Group III (G3) was submitted to the same procedure seven days after bleaching. After bonding, all teeth were stored in distilled water at $98.6^{\circ} \mathrm{F}$ for 24 hours. All groups were submitted to a traction test using an EMIC DL2000 universal testing machine at a speed of 0.5 $\mathrm{mm} / \mathrm{min}$. Results and Conclusion: The bracket resistance to debonding was compared between the groups by the Kruskal-Wallis nonparametric test $(\mathrm{p}<0.05)$ and it was verified that the bleaching agent significantly reduced bracket adhesion when bonded 24 hours after bleaching. However, seven days after bleaching, there was no significant difference on the resistance to debonding among groups G1 $(19,52 \mathrm{kgf})$ and G3 (18,44 kgf), meaning that it is necessary to wait longer after bleaching to bond brackets.

Keywords: Orthodontic brackets. Dental bleaching. Tensile strength.

Objetivo: o propósito do presente estudo in vitro foi avaliar a resistência de união de braquetes colados em pré-molares previamente submetidos ao clareamento com peróxido de hidrogênio a 35\%. Métodos: foram estudados 21 dentes pré-molares hígidos, divididos aleatoriamente em três grupos $(\mathrm{n}=7)$. O grupo I (G1) incluiu os dentes que não foram submetidos ao clareamento. As superfícies de esmalte dos grupos II (G2) e III (G3) foram submetidas ao processo de clareamento com peróxido de hidrogênio a 35\% (Whiteness HP Maxx). No grupo II (G2), após o clareamento, os dentes foram armazenados por 24 horas em água destilada a $37^{\circ} \mathrm{C}$ e, em seguida, braquetes metálicos para pré-molares foram colados utilizando resina Transbond XT (3M). O grupo III (G3) também foi submetido ao mesmo procedimento, sete dias após o clareamento. Após a colagem, todos os dentes foram armazenados em água destilada a $37^{\circ} \mathrm{C}$ por 24 horas. Todos os grupos foram submetidos ao teste de tração utilizando-se máquina universal de ensaios Emic DL2000 a uma velocidade $0,5 \mathrm{~mm} / \mathrm{min}$. Resultados e Conclusão: a resistência à descolagem dos braquetes foi comparada entre os grupos por meio da utilização do teste não paramétrico Kruskall Wallis $(\mathrm{p}<0,05)$, verificando-se que o agente clareador reduziu significativamente a adesão dos braquetes quando colados 24 horas após o clareamento. No entanto, 7 dias após o clareamento, não houve diferença na resistência à descolagem entre os grupos G1 (19,52kgf) e G3 (18,44kgf), sendo necessário, portanto, aguardar um maior tempo após o clareamento para a colagem de braquetes.

Palavras-chave: Braquetes ortodônticos. Clareamento dentário. Resistência à tração.

${ }^{1}$ Professor and Chairman, Specialization Course in Orthodontics, NOVAFAPI.

${ }^{2}$ Graduated in Dentistry, NOVAFAPI.

${ }^{3}$ Professor, Specialization Course in Orthodontics, NOVAFAPI.

${ }^{4}$ Specialist in Orthodontics, NOVAFAPI.

» The author reports no commercial, proprietary or financial interest in the products or companies described in this article.
How to cite this article: Rego MVNN, Santos RML, Leal LMP, Braga CGS. Evaluation of the influence of dental bleaching with 35\% hydrogen peroxide in orthodontic bracket shear bond strength. Dental Press J Orthod. 2013 MarApr;18(2):95-100.

Submitted: April 21, 2009 - Revised and accepted: November 16, 2010

Contact address: Marcus Vinicius Neiva Nunes do Rego Av. Lindolfo Monteiro, 1030, Bairro de Fátima, Teresina/PI - Brazil CEP: 64.049-440 - E-mail: mrego@novafapi.com.br 


\section{INTRODUCTION}

Based on the current beauty standards, where beautiful is to have white and aligned teeth, the search for esthetic treatment is the desire of most patients that seek for a dental treatment. ${ }^{9}$

Dental bleaching is the most popular esthetic treatment with the purpose of modifying tooth color. Among the bleaching agents, hydrogen peroxide is the most used for treating intrinsic staining of healthy teeth, presenting or not endodontic treatment. Hydrogen peroxide presents several concentrations and periods of application. ${ }^{10,20}$

There are evidences in the literature that the utilization of bleaching agents can interfere on the bond strength of orthodontic brackets. Prietsch ${ }^{14}$ concluded that dental bleaching with a 35\% hydrogen peroxide reduces bond strength after 24 hours, suggesting that a period of seven days should be waited after bleaching. On the other hand, Matta ${ }^{11}$ concluded that the bleaching agent with a 10\% carbamide peroxide increases significantly the mechanical bond strength of orthodontic brackets, and that the elapsed time from the end of the bleaching treatment to the bonding of the orthodontic brackets did not interfere on the mechanical bond strength when it was performed after 24 hours or one week.

However, according to Bishara et $a l,{ }^{3}$ bleaching with a $10 \%$ carbamide peroxide does not interfere on bond strength of dental enamel. Thus, despite researches reporting the effect of bleaching agents to the dental enamel, it is noticed that there is no consensus about the real interference on bond strength of orthodontic brackets.

Therefore, due to the increasing demand of adult patients for orthodontic treatment, associated to increasing care for dental esthetic, it is relevant to perform an evaluation of the influence of bleaching with a $35 \%$ hydrogen peroxide on the bond strength of orthodontic brackets.

\section{MATERIAL AND METHODS}

To perform the present study, twenty one healthy human teeth (premolars) were stored in distilled water at $98.6{ }^{\circ} \mathrm{F}$ for 24 hours. The teeth were, then, randomly divided into three groups $(n=7)$, according to waiting period post-bleaching ( 24 hours and 7 days) (Table 1$)$.
Table 1 - Description of the sample according to the procedures performed in each group.

\begin{tabular}{ccc}
\hline Groups $(\boldsymbol{n}=\mathbf{7})$ & \multicolumn{2}{c}{ Procedures } \\
& Bleaching & Bonding \\
\hline G1 & No & 24 hours \\
G2 & Yes & 24 hours \\
G3 & Yes & 7 days \\
\hline
\end{tabular}

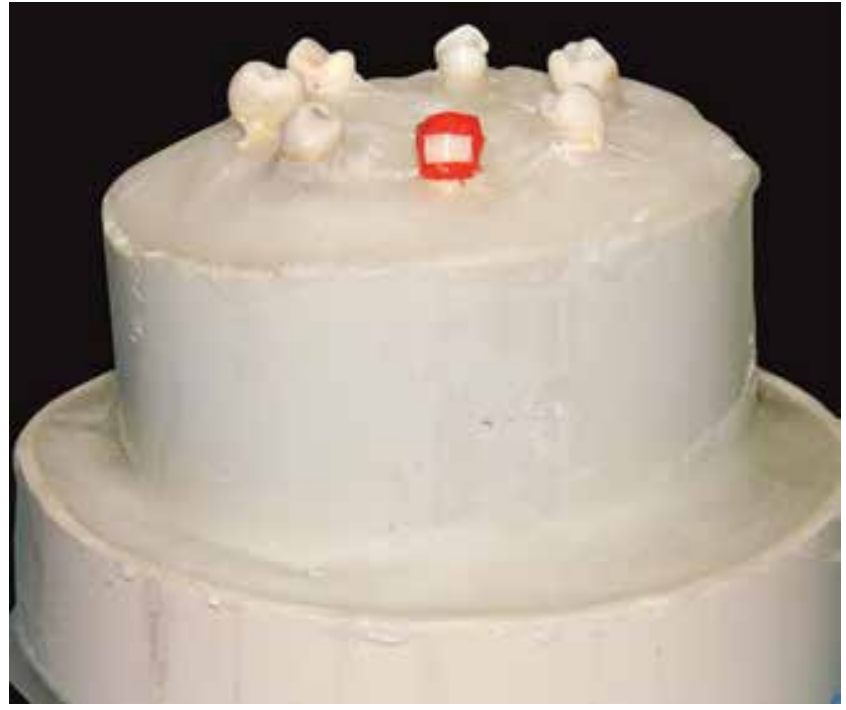

Figure 1 - Mounting the teeth with acrylic resin to the PVC bases.

Using self curing acrylic resin, each tooth was mounted in two PVC bases with different diameters, so that the buccal surface of each tooth formed a 90 degree angle with the acrylic base (Fig 1). This was necessary to standardize the traction tests in the universal testing machine.

Group I (G1) or Control group included the teeth that were not submitted to bleaching. For this group bracket bonding was performed according to the same protocol adopted for the experimental groups. The enamel surfaces of Group II (G2) and III (G3) were submitted to bleaching with 35\% hydrogen peroxide (Whiteness HP Maxx). The bleaching agent was applied for three times and activated by an halogen light, according to instructions from the manufacturer.

For Group II (G2), after bleaching, the teeth were stored for 24 hours in distilled water at $98.6{ }^{\circ} \mathrm{F}$, then, the area to be bonded to the bracket in each tooth was bounded by a mask made from adhesive tape ${ }^{11}$ (Fig 2A). After setting the mask, a prophylaxis with rubber cup 
and pumice paste and water was performed during 10 second for each tooth (Fig 2B), rinsing and drying (Fig 2C), with subsequent etching with 37\% phosphoric acid for 15 seconds (Fig 2D), followed by rinsing for 10 seconds and drying for 10 seconds ${ }^{11}$ (Fig 2E). Metallic brackets (Abzil) for premolars were bonded using the same amount of Transbond XT (3M) resin light cured for 40 seconds. All accessories were bonded at the same cervical distance, using a Boone gauge (Morelli) with a $4.0 \mathrm{~mm}$ distance (Figs $2 \mathrm{~F}$ to $2 \mathrm{M}$ ).
Group III (G3) was also submitted to the same procedures above described, but in this group the bonding was performed seven days after bleaching. After bracket bonding, all teeth were stored in distilled water at $98.6^{\circ} \mathrm{F}$ for 24 hours. Then, all groups were submitted to the traction test using an EMIC DL2000 universal testing machine at a speed of 0.5 $\mathrm{mm} / \mathrm{min} .{ }^{5}$ In this test the resistance values were obtained in kgf (kilogram-force) and registered by a printer attached to the machine (Fig 3A).
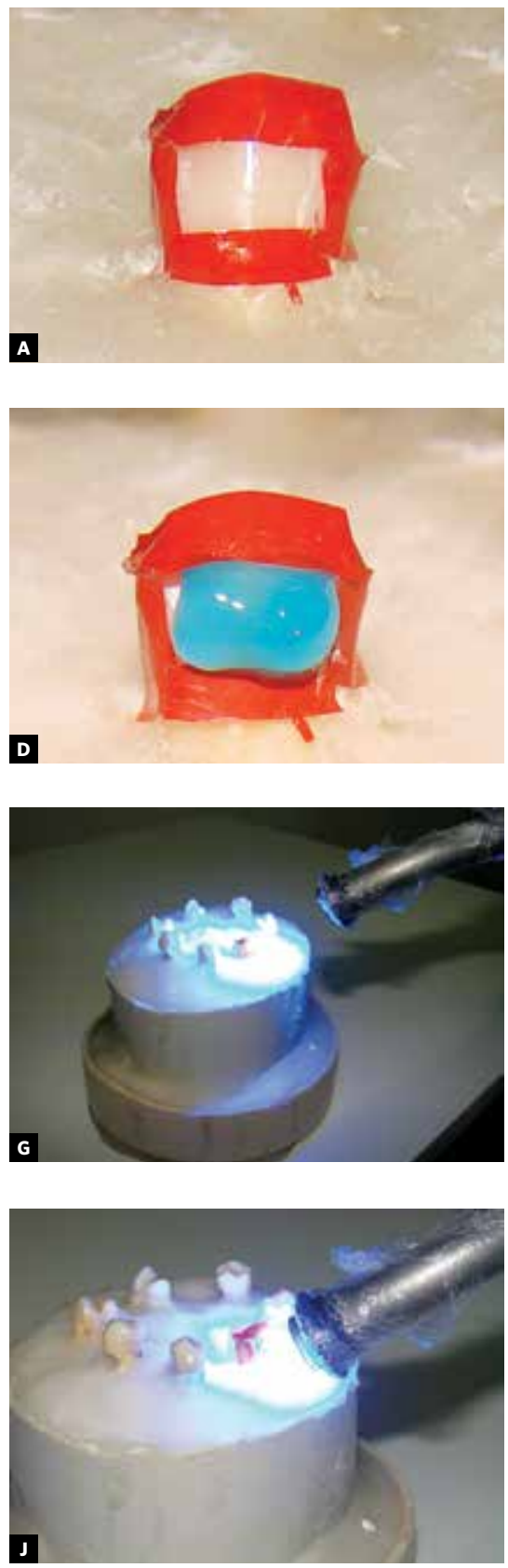
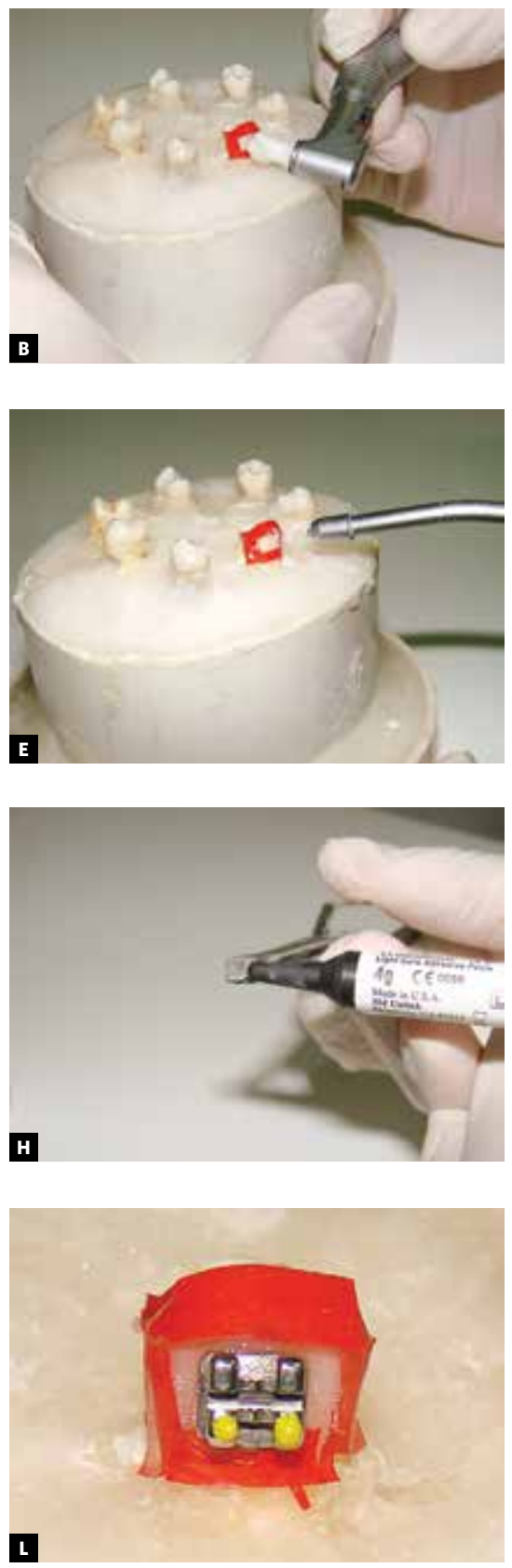

Figure 2 - A) Setting the mask. B) Prophylaxis (10s each tooth). C) Rinsing and drying. D) Acid conditioning (15s). E) Rinsing and drying (10s each tooth). F) Applying the primer. G) Photopolymerization of the primer. H) Applying the resin on the bracket base. I) Checking the distance of the accessory (4.0 mm). J) Photopolymerization. L) Bracket attached before removal of the mask. M) Bracket attached after removal of the mask. 
Then, a descriptive analysis of the mean and standard deviation for the tensile resistance (kgf) was performed for all groups.

The influence of 35\% hydrogen peroxide bleaching agent on the bonding strength of orthodontic brackets was evaluated comparing the traction force (kgf) results necessary to debond the accessories.

The Kruskal-Wallis nonparametrical test, with significance level of $5 \%(p<0.05)$, using the SPSS 13.0 was applied.

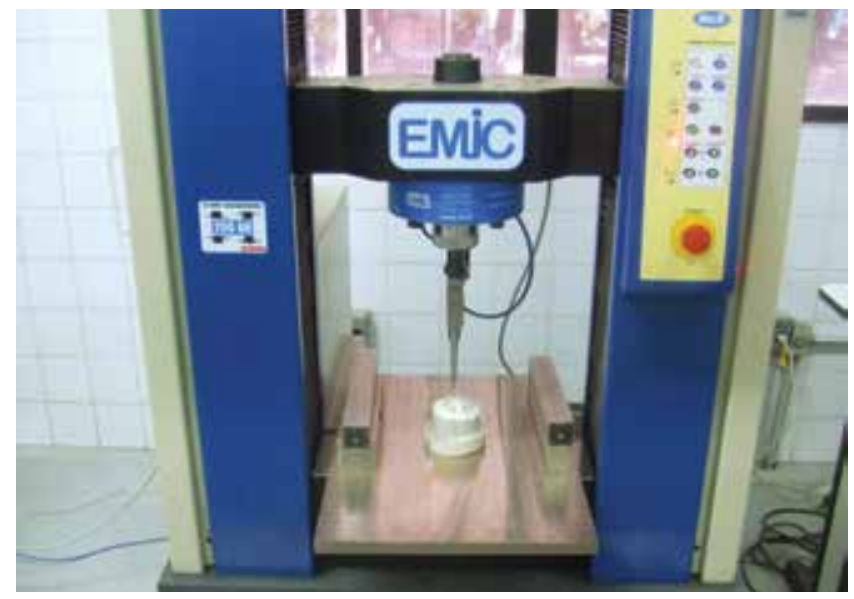

Figure 3 - Emic DL2000 universal testing machine.

\section{RESULTS}

The results (Table 2 and Fig 4) showed that there was a statistically significant reduction on the bond strength when compared to the Control group (19.52 kgf) and to the group where bonding was performed 24 hours after bleaching (12.31 kgf). When the bracket debonding strength was confronted with the Control group and the group where bonding was performed seven days after bleaching (18.44 kgf), it was noticed that there was no statistically significant differences.

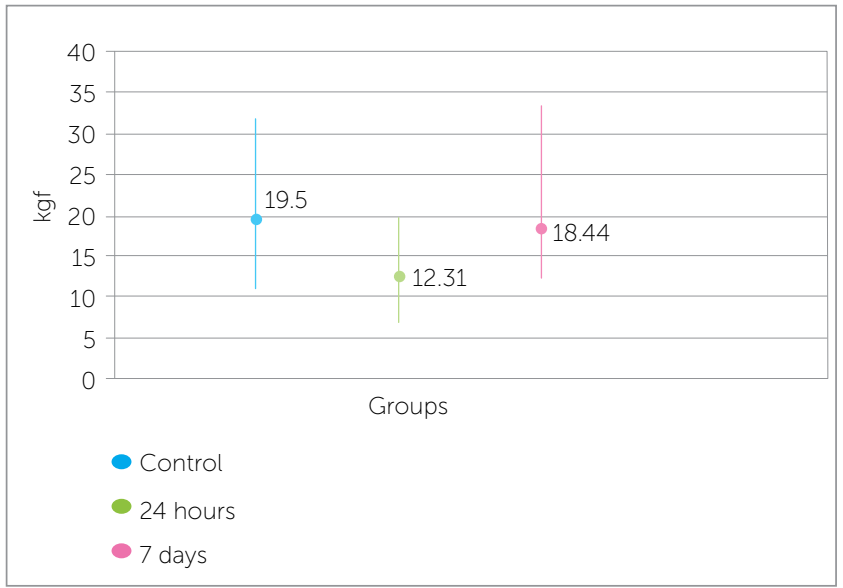

Figure 4 - Mean values and standard deviation of bond strength (kgf).

Table 2 - Bond strength values (kgf) obtained for each group according to tensile test.

\begin{tabular}{cccccc}
\hline Group & N & Minimum & Maximum & Mean & Standard Deviation \\
\hline control & 7 & 11.67 & 32.74 & $19.52^{\mathrm{a}}$ & 6.537 \\
\hline 24 hours & 7 & 8.01 & 18.17 & $12.31^{\mathrm{b}}$ & 3.240 \\
\hline 7 days & 7 & 11.42 & 35.78 & $18.44^{\mathrm{ab}}$ & 9.722 \\
\hline
\end{tabular}

Kruskal Wallis nonparametrical test $p<0.05$. Distinct letters $(a / b)$ represent that there was statistical difference.

Control $X 24$ hours $-p=0.025^{*}$. Control $X 07$ days $-p=0.098 .24$ hours $X 07$ days $-p=0.338$.

Table 3 - Evaluation of the influence of bleaching agents on the bonding strength of orthodontic brackets, according to existent studies

\begin{tabular}{|c|c|c|c|c|}
\hline Author & Type of tooth & Bleaching agent & Test & Resistance \\
\hline Matta, Maia, Chevitarese ${ }^{11}$ & Bovine & $10 \%$ carbamide peroxide & Shear & Increase \\
\hline Prietsch et $\mathrm{al}^{14}$ & Bovine & $35 \%$ hydrogen peroxide & Shear & Decrease \\
\hline Uysal et al ${ }^{21}$ & Humans & $35 \%$ hydrogen peroxide & Shear & No alteration \\
\hline Dishman et $\mathrm{al}^{6}$ & Humans & $25 \%$ hydrogen peroxide & - & Decrease \\
\hline Quintella $^{16}$ & Humans & $35 \%$ hydrogen peroxide & Shear & Decrease \\
\hline Miles et a ${ }^{12}$ & Humans & $10 \%$ carbamide peroxide & Traction & Decrease \\
\hline Homewood, Tyes, Woods ${ }^{7}$ & Humans & Hydrogen peroxide & Shear & No alteration \\
\hline Van der Vyver et al ${ }^{22}$ & - & Hydrogen peroxide & - & Decrease \\
\hline Bishara et $\mathrm{al}^{2}$ & Humans & $10 \%$ carbamide peroxide and $25 \%$ hydrogen peroxide & Traction & No alteration \\
\hline Bello, Souza ${ }^{1}$ & Humans & $10 \%$ carbamide peroxide & Traction & Increase \\
\hline Kraether, Souza ${ }^{8}$ & Humans & $10 \%$ carbamide peroxide & Traction & Increase \\
\hline
\end{tabular}




\section{DISCUSSION}

According to the literature on the influence of bleaching agents on the bonding strength of orthodontic brackets, there is still some doubt if these substances interfere negatively on bonding strength or not, since in some works there is a reduction on the adhesion, in others there is an increase and yet in some others there is no alteration (Table 3). A careful observation of these studies allows to number a series of variables that can explain the great variation in the results, such as: Type of bleaching agent, bleaching technique, type of enamel (human or bovine) and type of debonding tests (traction or shear).

The values obtained from the present study indicate a decrease on the bond strength of orthodontic brackets immediately after bleaching. These results were confirmed by others works, ${ }^{6,12,14,16,22}$ which also obtained a reduction on the bond strength depending on the waiting period post-bleaching. However, some authors ${ }^{1,8,11}$ presented different results and obtained an increase on the bond strength. The results found by Homewood et al, ${ }^{7}$ Uysal et $\mathrm{al}^{21}$ and Bishara et $\mathrm{al}^{2}$ showed no alteration on adhesion.

The reduction of bond strength can be explained by a significant decrease on the calcium/phosphorus relation on the enamel bleached with hydrogen peroxide, affect- ing adversely the dental hard tissues. ${ }^{17}$ Another reason for this decrease on the adhesion can be the fast decomposition of the residual bleaching agent, releasing oxygen into the porosities on the tooth surface. This oxygen has the capacity to inhibit the polymerization of the resinous material used in the procedures of bracket bonding, compromising the conversion degree of monomer to polymer and consequently, the union of the material with the enamel structure.

Therefore, the results of the present study suggest a waiting period of about seven days after bleaching to bond any accessory on the enamel surface, in order to minimize possible adverse effects of bleaching to adhesion.

\section{CONCLUSION}

From the results obtained in this in vitro study, it can be concluded that the dental bleaching with a $35 \%$ hydrogen peroxide, reduced significantly the bond strength of orthodontic brackets when bonding was performed 24 hours post-bleaching. However, after seven days from bleaching, differences were not noticed on bond strength, being recommended a longer waiting period when bonding of any accessory on the enamel surface submitted to bleaching agents is necessary. 


\section{REFERENCES}

1. Bello DRM, Souza MAL. A influência do branqueamento dental, in vitro, na colagem de brackets com cimento de ionômero de vidro modificado por resina. Ortod Gaúcha. 2000;4(2):87-100

2. Bishara SE, Oonsombat C, Soliman MM, Ajlouni R, Laffoon JF. The effect of tooth bleaching on the shear bond strength of orthodontic brackets. Am J Orthod Dentofacial Orthop. 2005;128(6):755-60.

3. Bishara SE, Sulieman AH, Olson M. Effect of enamel bleaching on the bonding strength of orthodontic brackets. Am J Orthod Dentofacial Orthop. 1993:104(5):444-7.

4. Bishara SE, VonWald L, Olsen ME, Laffoon JF, Jakobsen JR. Effect of light-cure time on the initial shear bond strength of a glass-ionomer adhesive. Am J Orthod Dentofacial Orthop. 2000;117(2):164-8.

5. Cal Neto JOAP, Miguel JAM. Uma análise dos testes in vitro de força de adesão em Ortodontia. Rev Dental Press Ortod Ortop Facial. 2004:9(4):44-51

6. Dishman MV, Covey DA, Baughan LW. The effects of peroxide bleaching on composite to enamel bond strength. Dent Mater. 1994;10(1):33-6.

7. Homewood C, Tyas M. Woods M. Bonding to previously bleached teeth Aust Orthod J. 2001:17(1):27-34.

8. Kraether J, Souza MAL. A influência do clareamento dental in vitro na colagem de brackets. Ortod Gaúch. 2002:6(1):6-16

9. Marcondes M. Eficácia de dois métodos de clareamento dental e sua influência sobre as propriedades físico-químicas e sobre a resistência à união de sistemas adesivos [dissertação]. Porto alegre (RS): Pontifícia Universidade Católica; 2006

10. Matis BA, Cochran MA, Eckert G, Carlson TJ. The efficacy and safety of a $10 \%$ carbamide peroxide bleaching gel. Quintessence Int. 1998:29(9):555-63.

11. Matta ENR, Maia JAC, Chevitarese $O$. Influência do agente clareador peróxido de carbamida a $10 \%$ na resistência mecânica da colagem de brackets ortodônticos. Rev Dental Press Ortod Ortop Facial. 2005:10(2):69-74
12. Miles PG, Pontier JP, Bahiraei D, Close J. The effect of carbamide peroxide bleach on the tensile bond strength of ceramic brackets: an in vitro study. Am J Orthod Dentofacial Orthop. 1994:106(4):371-5

13. Patel MP, Pinzan A, Francisconi PA, Pinzan CRM, Ferreira KB. Estudo da resistência ao cisalhamento na colagem de acessórios ortodônticos com e sem homogeinização da resina superbond. J Bras Ortodon Ortop Facial. 2004; 9(51):242-7.

14. Prietsch JR, Broilo JR, Spohr AM. Influência do clareamento dental com peróxido de hidrogênio na colagem de brackets ortodônticos: estudo in vitro. Ortod Gaúch. 2003:7(2):136-44.

15. Prietsch JR, Mainieri ET, Oshima HMS, Spohr AM. Colagem de bráquetes em cerâmica: revisão de literatura. Ortod Gaúch. 2005:9(2):142-8.

16. Quintella LPAS. Avaliação da força de adesão e tempos de espera na colagem de brackets ortodônticos, após clareamento dental com peróxido de hidrogênio 35 por cento: estudo "in vitro". Araçatuba; [s.n]; 2003. 135 p. ilus, tab.

17. Rotstein I, Dankner E, Goldman A, Heling I, Stabholz A, Zalkind M. Histochemical analysis of dental hard tissues following bleaching. J Endod. 1996:22(1):23-5

18. Surmont P. Dermaut L, Martens L, Moors M. Comparison in shear bond strength of orthodontic brackets between five bonding systems related to different etching times: an in vitro study. Am J Orthod Dentofacial Orthop. 1992;101(5):414-9.

19. Tavares CA, Zanini LK, Borges $L$. Estudo clínico comparativo da retentividade de brackets ortodônticos. Rev SOB. 1998;3(6):225-8.

20. Tytley KC, Torneck CD, Smith DC. The effect of concentrated hidrogen peroxide solutions on the surface morphology of human tooth enamel. J Endod. 1988;14(2):69-74.

21. Uysal T, Basciftci FA, Usümez S, Sari Z, Buyukerkmen A. Can previously bleached teeth be bonded safely? Am J Orthod Dentofacial Orthop. 2003:123(6):628-32.

22. Van der Vyver PJ, Lewis SB, Marais JT. The effect of bleaching agent on composite/enamel bonding. J Dent Assoc S Afr. 1997 Oct;52(10):601-3. 